\title{
A Rose Will Never Bloom: Doomed Tragedy of Miss Emily
}

\author{
Yuying Zhang \\ School of Foreign Languages Jilin Business and Technology College Changchun Jilin China \\ Email:511325882@qq.com
}

\begin{abstract}
Keywords: Doomed, tragedy, female
Abstract. In "A Rose for Emily”, Miss Emily Grierson was a morbid woman living in isolation because of the lifelong persecution of patriarchy, family, tradition, and Puritanism. Moreover, she became the monument of her era, and her death signified the fallen monument (Faulkner) and the end of aristocratic era. All her life, Miss Emily could not do anything at her own will, and it seems everyone would stand out to interfere with her when she was doing something inconsistent with the traditions. It is not surprising that such a woman under these strong controls and restrictions would become so morbid that she refused her father's death, killed her lover, and even slept with the corpse to affirm her victory over the earthiness. Miss Emily was the victim of the tradition and society and her life was doomed to be tragic.
\end{abstract}

\section{Introduction}

With particular history and tradition, American Southern aristocratic families once enjoyed affluent life and exquisite aristocratic civilization. However, after the Civil War, American South entered into a new era, when slaves were celebrating the end of slavery, other southerners were doing their utmost to preserve the dying tradition and aristocratic prestige. Meanwhile, the aristocrats experienced severe torments when their traditional life mode and sense of values struggled desperately and vainly in the shadow of defeat and poverty. In A Rose for Emily, Miss Emily Grierson was considered as the monument of her era, and represented the aristocratic tradition, duty and responsibility, and when she died, the monument fell and aristocratic era ended.

\section{Character of Emily}

Emily was a cold and arrogant virgin living in isolation, whose youth had been devoured by the social traditions and doctrines. All her life, Emily could not do anything at her own will, and it seems everyone would stand out to interfere with her when she was doing something inconsistent with the traditions. When her father was alive, he gave on freedom for Emily on her love and marriage. After her father's death, Emily's aspiration for freedom and marriage had been liberated from the long suppression. However, Homer Baron's refusal and social pressure deprived her of feminine goodness and the last ray of hope for life. Under such lifelong persecution, it is not surprising that she became so morbid and chose to live in seclusion, and her life was doomed to be tragic. From the perspectives of feminism, Old South's patriarchy, family, tradition, and Puritanism are dealt with to reveal their adverse influence upon Emily's life, so as to explain Emily's unexplainable refusal on her father's death, murdering her lover and sleeping with corpse, in terms of psychoanalysis, and to present the conflicts among the id, ego and superego in this novel.

Born in a family of aristocracy and an age of patriarchy, Miss Emily was subjected to his father's supreme authority, was deprived of everything by her father, even her right as the human, and she could only live as an object of her father. In those days, the pride of aristocratic family was prevalent and Puritanism was deeply rooted. Her father drove away all the young man pursuers of Emily and deprived her of any acceptable form of love (Nebeker). It seems that all those young men were not good enough for Emily and such aristocrats (Faulkner). Marrying those people would ruin the family's reputation and pride. Emily's obedience and father's supreme authority can be fully illustrated by the tableau of Emily and her father. Her father's influence was so strong over her that 
even after her father died, Miss Emily refused to admit his death and tried to cling to him who robbed her of everything (Faulkner). Evidently, it is the cruel patriarchy and family pride destroyed Emily's humanity and caused her tragic life.

Being left alone, after father's death, Miss Emily would become humanized (Faulkner), but she still could not escape the patriarchal oppression, only lived as a bird in a cage and a property of new owner. When Homer Baron arrived at Emily’s town, Miss Emily fell in love with this Yankee instantly regardless of their status difference and her family pride. Miss Emily's yearn for the future happy marriage was so strong that she devoted all her love to Homer Baron, planned to marry him, and prepared their marriage. Unfortunately, this seemingly happiness turned to be a love tragedy at last. Homer Baron had remarked that he liked men (Faulkner), and might take use of dating with Emily as a cover for his true sexual orientation. Emily's dream was crushed again by the cruel reality, and there arose her sadness, hatred and desperation for the life and for Homer Baron. Miss Emily could not remain quiet and sober any more, she had to do something. Two most important men in her life, father and lover, deprived her humanity, destroyed her hope for a normal life, overturned her pride and finally ruined her life completely. It is not surprising that she turned to be so morbid to kill her beloved man to claim her final victory over his betrayal and spiritual persecution. Even though Homer Baron would marry Emily rather than dissert her, she might not escape the control of patriarchy.

\section{Emily's Tragedy}

\subsection{Feminist analysis of tragedy}

American feminist activist, Roxanne Dunbar - Ortiz once made a statement that, the tragedy of female does not lie in their lower social status or physical weakness, but in the prevalent, deep-rooted social malady, which makes all females live in the same international institution that is dominated by male. To liberate female, the word "feminism" first appeared in France, and later was used more widely around the globe. During women's movement of the 1960s and early 1970s, the subjects of feminism includes women's experience under patriarchy, female's suppressed voice under the man-rule tradition, their peripheral role in the social life and distorted wretched life (Rivkin \& Ryan). Currently, feminism embraces a wide range of theories to fight against social inequality, to save them from the male dominated environment, and to promote female's right and interest. In the most basic sense, feminism is the movement for social, political and economic equality of men and women and provides an effective approach to analyze female's life in reality and literature works.

Western feminism falls into three waves, and each deals with female's problems from different perspectives. The first wave, from nineteenth to early twentieth century, focused on women's equal rights with men, particular their suffrage. During the mid-twentieth century the second wave relied more on Simone de Beauvoir's Marxist documented in The Second Sex to solve many questions of feminism. Meanwhile, literal and radical feminists tried to liberate women from the perspective of gender and patriarchy. Then the third wave appeared in 1990s, and was a response to the failure of second wave, which utilized a post-structuralist view to interpret gender and sexuality. Of three waves, there are many different types of feminisms, such as conservative, liberal, radical, cultural, Marxist, essentialist and post-modern. No matter which types of feminism are present or going to emerge, one thing is certain that they all endeavor to fight against any unjust treatment of women and to enable them to achieve the equality of gender in every sphere of life.

\subsection{The Reason of Emily's Tragedy}

\subsubsection{Relation between id, ego and superego}

Psychoanalysis conceived by Austrian psychologist Sigmund Freud, is a psychological theory studying rational and irrational human behaviors and experiences that are acted by consciousness or unconsciousness. "Freud spend most of his life studying the boundary and the dynamic movements between the conscious self or ego and the unconscious, which he later came to call the id" (Rivkin \& Ryan). Id is the reservoir of human inborn instinct, especially sexual instinct and aggression, which is 
usually irrational and disordered, and is acted on pleasure principle. Superego acts like a procurator and of the brain, and reminds individual of the criterion of social and cultural civilization. While the conscious ego performs like an arbiter and mediates the demands of id and the judgments of superego, thus helps individual to avoid acting in a harmful way, but in a manner acceptable in the real world. The personality structure of id, ego, and superego is not stable and do not remain unchanged, rather each part of the structure always interacts, contradicts, and fuses with the others in the process of psychological activities. Close contact and communication among id, ego and superego enables to get one's basic needs satisfied, and to achieve ones' aim under moral restraint. Restrained by the conscious ego and superego, unconscious drives of id are often suppressed, but they cannot be entirely eliminated. Rather these irrational drives might appear in their dreams, when the rational part of mind fails to handle them successfully, or they are expressed directly in reality when conscious control breaks down altogether (Rivkin \& Ryan). One of the psychological theories proposed by Freud is Oedipus complex, which denotes a boy's desire to sexually possess his mother that is kept in the unconsciousness. However, when the conscious control collapses, this irrational drive would be displayed by killing his father and marrying his mother. As for the girl, it is likely to embed the same longing for her father and compete with her mother for love and possession, and this phenomenon is termed as Electra complex by Carl Gustav Jung. As a girl grows up, she might end her Electra complex by marrying another man. If this unconscious drive is left unsolved, it would be developed as a hidden psychological disease and propels her to do something irrational and incomprehensible.

\subsubsection{Patriarchal suppression}

In addition to the patriarchal suppression from her father and lover, Miss Emily endured more, since she had to been subjected to the control of traditional values and the persecution of Puritanism. Several decades after the Civil War, though the new industry began to emerge in people's life, the southern people, especially the old generation still clung to the southern traditional morals. During Emily's dating with Homer Barron, the town's people and her relatives continued to force Emily back to the "right track" if she was doing something improper according to the traditions. Though some of the town's people were happy at first, when they saw Emily had an interest in Homer Baron, still the older people said that even grief could not cause a real lady to forget her noblesse oblige (Faulkner). The older people thought this did not only bring disgrace to herself, but also to the whole town. No matter how much sympathy they had for Miss Emily, they still could not liberate their mind, still could not liberate Emily as a real human, but keep her as the monument to reaffirm their deep root in the tradition. As a descendant of the aristocratic family, Miss Emily must abide by the moral standard of the southern aristocratic society to maintain her nobleness and symbolize southern fair lady with elegance and chastity in accordance with Puritanism. Apparently, Miss Emily's driving about the street with Homer Baron was truly against the Puritanism, destroyed her image as the fair lady, and set bad example for the young people. The town's people could not bear such shame to the whole town, so after Baptist minister failed to persuade Emily's misconduct, minister's wife wrote to Emily's relative to stop her. The entire town's people and her relatives had destroyed Emily's love and her last straw. They believe that Miss Emily had degenerated, so when they saw her buy arsenic, they all said, "She will kill herself, and it would be the best thing." (Faulkner). They would rather like Emily to kill herself to maintain the routine than to let her ruin the tradition and disgrace the town.

\subsubsection{Inner reason of Emily}

As the symbol of the decayed southern slavery system, Miss Emily lived in an age of past and refused to come terms with the changes of the new era, and her psychological morbidity was inevitable because of her lifelong living in a declining and collapsing society. No mention of her mother, Emily had stayed and lived with her father until he died, and the phantom of her father loomed throughout the rest of Emily's life. Growing up in a family without mother and relying on father all the time, in her sub-consciousness, father was her spiritual prop, and it is reasonable that Emily might develop the Electra complex. Alive, her father strongly interfered with Emily's life and unconsciously influenced Emily's spiritual independence and psychological health. Maybe out of the aristocratic tradition or 
his desire of possessing her for himself, Emily was forbidden to pursue her love and was still a virgin when she was thirty. As the aristocracy declined, Emily's chances of finding her soul mate became even slimmer, and her dependence on her father grew more intense. Not surprisingly, she refused to bury her father, since she could not accept the sudden spiritual loss and live on her own. After father's death, Emily's Electra complex did not die out, rather developed into the extremity. She tried to prolong her Electra complex upon Homer Barron to sustain the spiritual dependence and sense of safety. However when she found that Homer was not to marry her, her panic of loss aroused again and she decided to keep him by her side to replace her father in this house. At last, she poisoned him and slept with his corpse, and this action manifested her morbid Electra complex to the utmost. Judging from Freudian theory, such morbid psychology is rooted in her suppressed sexual desire.

\section{Conclusion}

Conflicts between Emily and the rest of the people in the novel is just like the interrelationship among Freud's id, ego and superego, each is represented by Emily, town's people and new aldermen and her relatives respectively. Representing id, Emily acted on pleasure principle, when she disregard the acknowledged social morality and accepted conduct, and ceaselessly satisfied her desire in spite of moral restriction. She never thought about the relationship between her desire fulfillment and social morality, and even did whatever irrational to bring "happiness" for her. Besides, Emily stood for the primitive impulse and human instinct, especially sexual desire. As the symbol of morality and authority, new aldermen and Emily's cousins are superego. They functioned to suppress Emily's instinctual impulse, and performed on moral principles, when they interfered with Emily's marriage with Homer Baron. However, in the novel, id had never been suppressed by the conscious superego. Town's people symbolized ego and were spokesmen of the reality. Though ego did not approve id's pleasure principle, town's people realized that Emily was the victim of the declining southern aristocracy after the Civil War. They offered their sympathy and relief for Emily when her father died, they helped Emily when her cousins were under her roof, and they attended her funeral to give their respect. Living in a crack between the past and reality, Emily aspired to get a red red rose, but ended up with a dried rose bud that never bloomed. The poison of patriarchy, social tradition and Puritanism had endlessly sprayed on her new bud until the rose died. However, Emily still would not give it up, but let it dry to be kept forever as her silent protest and final victory.

\section{References}

[1] Barnet, Sylvan, William Burto, and William E. Cain. Literature for Composition: Essays, Stories, Poems, and Plays. Boston: Longman, 2011. Print. pp.237-244

[2] Faulkner, William, and Noel Polk. A Rose for Emily. Fort Worth: Harcourt College, 2000. Print.

[3] Nebeker, Helen Emily's Rose of Love: Thematic Implications of Point of View in Faulkner's "A Rose for Emily" The Bulletin of the Rocky Mountain Modern Language Association, Vol. 24, No. 1 1970, pp. 3-13

[4] Powell, Janice. "Changing Portraits in 'A Rose for Emily”' Southeast Missouri State University. 18 February 2011. < http://www.semo.edu/cfs/teaching/index_4883.htm>

[5] Rivkin, Julie, and Ryan, Michael. Literary Theory an Anthology. Malden (Mass.): Blackwell, 2004. Print. pp.391\&755 